\title{
XXXV. On the blue colouring-matter of lapis lazuli, and on artificial ultramarine
}

\section{Dr. Fr.W. Schweigger-Seidel}

To cite this article: Dr. Fr.W. Schweigger-Seidel (1830) XXXV. On the blue colouring-matter of lapis lazuli, and on artificial ultramarine , Philosophical Magazine Series 2, 7:40, 244-250, DOI: $10.1080 / 14786443008675282$

To link to this article: http://dx.doi.org/10.1080/14786443008675282

Published online: 13 Jul 2009.

Submit your article to this journal $₫$

Џ Article views: 7

Q View related articles $\llbracket$ 


\section{Dr. Scluweigger-Seidel on the Blue Colouring-matter}

The several points I have enumerated place the theory of the figure of the planets upon grounds entirely new. I conceive that the views I have developed are important, both because they overcome a difficulty insuperable in any other way, and because they will facilitate the progress of knowledge by superseding much of the abstrusest and least satisfactory writings on the celestial mechanics. My only object in what $I$ have written is to assert and prove my claim to what $I$ have discovered, by my own labour, in spite of much unprecedented opposition. I put myself in comparison with no one; I will enter into no altercation on the subject; I merely claim what I have the justest title to claim; nor do I think it necessary at present to explain particularly the reasons that have induced me to write this letter.

It may be proper to add that the subject of this letter has no connection with another contestation, entirely mathematical, relating to the series for computing the attraction of spheroids. I remain, Gentlemen, yours, \&c.

March 8, 1830.

JAMES Ivory.

XXXV. On the Blue Colouring-matter of Lapis Lazuli, and on artificial Ultramarine. By Dr.Fr.W. SchWEIGGER-SEIdEL.**

rTHE mineral colour known by the name of Ultramarine, esteemed for its beauty and durability, especially in oilpainting, has long been an object of chemical inquiry. The lapis lazuli, from which the colour is obtained by careful washings, is procured from Asia (partly through the East Indies, partly by way of Orenburg), where it is found in Little Bucharia, Thibet, several provinces of China, and Siberiat. It seems to have been known to the Romans under the name of Sapphire, as appears from some passages of Plinyt. But the production of ultramarine seems not to have been invented till the end of the fifteenth century; the name of Azurrum ultramarinum (the origin of which is very evident) is said to have been first used in the year 1502 by Camillus Leonarius $\S$. It once formed a considerable article of trade in Italy, where this colour was probably first produced, and even now the greatest quantity, and that of the best quality, comes from there.

* From the Jahrbuch der Chemie, \&c. N. R. Band xxii. p. 206.

$\dagger$ This is different from the lazulite or copper lazure (Armenian stone), which owing to the similarity of their colour used formerly to be mistaken for it; hauyn seems to be more nearly related to lapis lazuli.

† Hist. Nat. lib. xxxvii. 38,39 .

\$ Iacuchs's Farben-und Färbekunde, ii. 198. 
Whether it be in consequence of a lessened demand, and consequent diminished manufacture since the discovery of prussian blue, and other cheaper blues, or in consequence of a diminished importation of the lazure-stone, that this colour has become so very scarce, this much is certain, that its high price (an ounce of the best quality being said to sell now at from one hundred to two hundred francs*) has greatly limited its use; whilst formerly, especially in the sixteenth century, it was almost wasted by painters, as is proved by many pictures of that period.

The value of the colour naturally led to a desire of producing it artificially. Some assert, that the art was known in the sixteenth century, but kept secret. But this probably implied only the art of obtaining ultramarine of the best quality from the lazure-stone. What are called artificial lazure-stones, for the production of which there are many formulat, are in fact artificial pieces of glasses coloured with some metallic oxide (mostly oxide of cobalt), which will of course yield no ultramarine. Indeed the colour of lapis lazuli was generally ascribed, until lately, from the results of chemical analyses, and according to analogy, from a metallic oxide (oxide of cobalt, copper, iron, \&c. supposed to be contained in it). Wallerius derives it from silver $f$, which, however, has not been found by any modern chemist, and which was probably only believed to be it through a well-known mistake usual in former times. The common opinion, however, was, that the blue colour of the mineral was produced by oxide of copper, until it was shown by Marggraf, that the lazure-stone contained oxide of iron only, and no oxide of copper $\S$. It was his analyis which gave the first explanation of the component parts of this stone; for the accounts of Rinmann and Cronstedt are not sufficiently defined. Klaproth's subsequent analysis \| generally confirms the results of that of Marggraf, except that he points out a portion of alumina which the latter overlooked; for the rest, he also inclined to the opinion that the blue colour was produced by the oxide of iron. It was Guyton de Morveau who first drew public attention to a portion of potash contained in the lazurestone, and which he thought accidental, but considered that it

* Leuchs's Farben-und Färbekunde, p. 905. Thénard Traité de Chimie, tom. ji. (618) p. 210 .

+ Compare some of them in Leuchs, p. 487.

\pm System. Mineral. i. 312.

f See his Chemical works, vol, i. p. 121-134, and Hochheimer's Chem. Minéralogie, vol, i. p. $239-244$.

|| See Beiträge, \&c. vol. i.p. 180-196, and Schweigger's Journal, vol. xiii. p. 488. xiv. p. 531. and xli. p. 234 . He found silica and alumina, carbonate of lime, sulphate of lime, and oxide of iron. 


\section{Dr. Schweigger-Seidel on the Blue Colouring-matter}

was chiefly the sulphur it contained which, combined with the iron, produced the colouring matter of the stone*. This view, however, was refuted by Clement and Desormes, who proved that the ultramarine contained sulphur, but no iron†; which conclusion was confirmed by the experiments of $R$. Phillips, on the methods of ascertaining the degree of purity of the ultramarinef. Clement and Desormes at the same time mentioned a considerable proportion of soda in the ultramarine, which also seemed to contain some potash $\$$. These two chemists, however, express no opinion as to the cause of the blue colour. 'Thénard, indeed, does not deny the possibility of a coloured body being produced by the combination of colourless bodies, but adds that the loss of 0.8 per cent, experienced by MM. Clement and Desormes in their analysis, might lead to the supposition that it was just the colouring substance which had escaped them\|. Phillips expresses the opinion that the lazure-stone perhaps owes its colour to a peculiar substance not metallic, and recommends this part of the subject to the attention of chemists $\pi$.

With this difference of views on the nature of the colouringmatter in the lazure-stone, scarcely any result could be expected from the experiments instituted for producing ultramarine artificially; indeed they were all unavailing. An interesting accident, however, had led to a probable hope of the result ultimately turning out advantageously. M. Tassaërt,

* Compare Scherer's Joumal (1800), vol. iv. p. 659, and more at large vol. v. p. 709; also Ann. de Chimie, xxxiv. p. 54, and Von Crell's Chem. Ann. 1801, p. 467: he notices the following substances as appearing accidentally in various quantities in the lazure stone,-carbonate and sulphate of lime, and at times even barytes.

† Gehlen's Journ. für Chem. u. Phys. vol. i. p. 214-221, and Ann. de Chim. March 1806, tom. lvii. p.317-364. Compare also Journ. des Mines, xvii. (No. 100 ) p. 322; and this (Schweigger's) Journal, vol. xiii. p. 489; vol. xiv. p. 33l, and vol. xli. p. 235.

$\mp$ Vol. xli. of this (Schweigger's) Journal, p. 233-24l. Comp. also Annals of Philosophy, No. 51, July 1823, p. 31. The methods of examination are given here with mountain blue, prussian blue, indigo, smalt, and oxide of cobalt, although we may venture (as Phillips says at p. 239) to declare an ultramarine as genuine, which in a few minutes "(developing sulphurous acid gas, especially on being heated)" loses its colour when an acid is poured on it, leaves an insoluble dirty white residue, and forms a colourless solution.

$f$ They at least saw crystals of alum, like Guyton de Morveau. They found no sulphurous acid gas, and even carbonate of lime does not always appear; but always sulphur in connection with soda, alumina and silica, which therefore must be considered as the essential components of the ultramarine.

II See his Traité de Chimie, I ${ }^{*}$ A. tom. ii. p. 208; and Schweigger's Journal, vol. xli. p. 236 .

fI In this (Schweigger's) Journal, vol. xli. p. 239. 
stiperintendent of a manufactory of sulphuric acid and soda, found, on breaking up the hearth of one of his smelting furnaces for soda, in the foundation of it, a blue substance which as long as the hearth had been built of brick, and not of sandstone as it was then, he had never noticed*. Vauquelin on examining this substance found it greatly to resemble the lazurestone, and the analysis also indicated alumina and silica united with soda and sulphite of lime, but at the same time with iron and sulphuretted hydrogen, from which latter components in connection with alkali Vauquelin felt inclined to deduce the blue colour of this substance as well as of the lapis lazuli $t$. Soon after L. Gmelin examined a volcanic product thrown out by Vesuvius, which Breislak (in his Voyages dans la Campanie) mentions as a seventh kind of lazulite, and which was afterwards classed by Bruun Neergard with the hauyn $\neq$. Nevertheless this mineral seemed to agree in its exterual characters more with the lapis lazuli than with the hauyn, which induced L. Gmelin to repeat the analysis of lapis lazuli at the same time, and to compare the results of these analyses with those he had recently obtained from the chemical investigation of the hanyn $\$$. The result was, that the blue volcanic product above mentioned had in reality a great similarity with the lazure-stone even in its chemical composition. But the same observation was also applicable to the hauyn, which seemed to differ from the lazure-stone, essentially, only by a proportionately great quantity of sulphuric acid, and by its containing potash instead of the soda found in the lazure-stone. The latter, however, was also the case in the blue volcanic mineral, by which the latter seemed again more closely related to the hauyn than to the lapis lazuli, or at least to form an intermediate link between the two minerals. This induced L. Gmelin to arrange the lazuli, containing soda, with the hauyn, containing potash, as species or subspecies nearly allied, but to consider the blue mineral, under the name of earthy hauyn, as a mere variety of the common, called granular hauyn. In other respects the volcanic product differs from the two other

* According to a verbal communication of Dr. W. Weissner, the administrator Herrman at Schönebeck had made a similar discovery snme y'ears ago, and declared the substance to be an ultramarine produced by a chemical process. Perhaps we ought also to add to this the blue colouringmatter which at times dyes the calcined potash a beautiful lazure blue, and which has been usually attributed to metallic oxides or finely divided carbon.

† Compare this (Schweigger's) Journal, vol, xiii. Old Series, p. 486, \&c. and vol. xiv. p. 333 . Ann. de Chim. tom. lxxxix. p. 88. Thénard, ton. ii. p. 748. Fechner, ii. p. 418.

$\ddagger$ Joum. des Mines, No. 195 .

$\S$ Observationes Geognostica et Chemica de Hauynâ, \&c. 


\section{Dr. Schweigger-Seidel on the Bluc Colouring-matter}

substances by containing a considerable proportion of iron : L. Gmelin, however, also found iron in the lazuli, and he would not have been disinclined to take the colouring principle for protosulphuret of iron, had not Clement and Desormes shown that there is no iron in the ultramarine.

Almost at the time when Vauquelin's and Gmelin's investigations of substances resembling lazulite* (which evidently were indebted for their existence to chemical processes nearly related,) raised the possibility of an artificial production of ultramarine almost to a certainty, without, however, giving any clear explanations respecting it, another German chemist (who has not only enriched the science in so distinguished a manner, but also the arts by a number of ingenious investigations) found in quite a different way an indication of the colouring-matter in the lazuli, and he would have required but little further investigation to become perfect master of the artificial production of ultramarine.

By the communication of some experiments on the fuming sulphuric acid, which were published in the year 1815 in this (Schweigger's) Journalt, Doebereiner developed his views on the composition of sulphur, as consisting of hydrogen and a probably metallic body (schroefelstoff), whence he felt inclined to deduce the blue colour of Vogel's blue sulphuric acid. "And if," concluded this able chemist, " the colour of the pure sulphureous substance is really blue, the colour of the ultramarine seems to be solely produced by this substance; and that from potash or soda, sulphur, silica and alumina, under certain conditions, a blue similar to the ultramarine, only less brilliant and beautifully clear, may be produced, I have shown a year ago to Professors Gehlen and Schweigger. I have been withdrawn from this investigation by other occupations, but shall soon again devote myself to it, and communicate the results." He, then, was the chemist who for the first time pronounced the colouring principle of ultramarine to be sulphur.

Unfortunately Dœbereiner has not again pursued his beautiful discovery: it is therefore the more satisfactory that the fact is now confirmed in many journals, with the intelligence which, no doubt, will please the practical chemists, that another of our most distinguished German chemists, Professor C. G. Gmelin of Tubingen, has succeeded in the discovery of a proper chemical process for the production of ultramarine.

* See this (Schweigger's) Journal, vol. xiv. OId Series, p. 325-335, where at p. 331 a tabular view is given of the analyses here alluded to. Let it also be observed that Gmelin found traces of potash besides the soda in the lazuli, and 2 per cent of magnesia.

+ Vol. xiii. Old Series, p. 476-484. 
We cannot conclude this review more suitably than by a verbal transcript of the following account from the Berliner Hand und Spener'sche Zeitung, (10th April 1828,) No. 81, and which in substance seems to be from the distinguished inventor himself.

"Tübingen.-Prof. C. G. Gmelin, who for some time past has been employed in the investigation of ultramarine, has arrived at the conviction that sulphur is its colouring principle, and particularly that there is no metal, properly so called, entering into its composition. Gmelin had received some ultramarine from Paris eighteen months ago, but which, according to the opinion of M. Seybold, the artist at Stuttgard, was not of the best quality. In order, therefore, to obtain ultramarine of all kinds, and to determine by strict analysis what proportions of its component parts are most favourable to the production of its fiery colour, he addressed himself months ago to Prof. Carpi at Rome. During a short residence he made in Paris, in the spring of 1827 , he expressed it as his opinion to the chemists of that metropolis, especially to M. GayLussac, that ultramarine, with the investigation of which he told them he was then engaged, might be produced artificially. It is perhaps, therefore, his own fault if another (M. Tunel of Paris, who wishes to keep his discovery a secret) has anticipated him in this respect. The process by which, according to M. G.'s inquiries, the production of ultramarine is always successful, is the following:-Procure silica containing water and alumina; calculate how much a given weight of these earths will leave after being calcined. (By Gmelin's investigations 100 parts of hydrous silica contained only 56 , and 100 parts of hydrous alumina only $32 \cdot 4$ parts of pure earth.) Next, dissolve as much of the hydrous silica as can be dissolved in caustic soda, and calculate the quantity of earth used. Add now to 72 parts of this silica, (calculated as free from water,) 70 parts of alumina (also calculated in a state free from water); add the latter to the silicate of soda, and let it evaporate, stirring it all the time till the residue presents a damp powder. (One may also take at once 60 parts of dry caustic soda to 72 parts of alumina obtained from alum, the latter being reduced to the dry state.) This colourless mixture of silica, soda, and alumina, is the foundation of the ultramarine, which is to receive its blue colour. For this purpose, melt in an earthen crucible, well closed, a mixture of two parts of sulphur and one part of anhydrous carbonate of soda, and when the mass is properly melted, throw very small portions of the first mixture at once into the middle of the crucible: as soon as the effervescence

N.S. Vol. 7. No. 40. April $1830.2 \mathrm{~K} \quad$ pro- 


\section{$250 \mathrm{Mr}$. De la Beche on the GeographicalDistribution of Organic}

produced by the rising of the aqueous vapours has ceased, throw in another portion, and so on; and keep the crucible, when the whole mixture has been introduced, for about one hour in a moderate red glowing heat (if the heat is too great, it destroys the colour); when cold, pour water into the crucible, and separate by means of it the brown residue of sulphur mixed with the ultramarine. A superabundance of sulphur may be expelled by a moderate heating. If the colouring is not of an equal intensity, the most fiery ultramarine (and this is a very important circumstance) may be obtained by washing, and separating it from those parts which are less coloured. From the component parts of the ultramarine as given by the analysis, it cannot be formed, without a medium. Thus this colour is nothing else than a silicate of soda dyed with sulphuret of sodium.

"The natural ultramarine contains a not inconsiderable portion of potash and sulphuric acid; and it is very probable that the artificial production here mentioned may be usefully varied, but this can only be discovered by experiment."

XXXVI. Notes on the Geographical Distribution of Organic Remains contained in the Oolitic Series of the Great London and Paris Basin, and in the same Series of the South of France. By Henry T. De la Beche, F.R.S. \& c.

[Continued from page 205.]

Lowest System.-Subdivisions': Cornbrash, Forest Marble, and Great Oolite.

I T has been considered that the former of these is a proper subdivision, and may be traced to considerable distances, but that the two latter may pass into or represent each other. Great difficulty must always attend these minute divisions. Mr. Phillips gives only five feet as the thickness of the cornbrash in Yorkshire; it is represented as from eight to sixteen feet in the neighbourhood of Tellisford and Farley Castle, near Bath; M. de Caumont doubts its existence in Calvados, though there is a rock which $M$. Desnoyers and myself consider may be referred to it; and M. Boblaye mentions it in the North of France, but it does not so clearly appear to exist in the South of the same country. The forest marble and great oolite seem to occur extensively. In Calvados the latter, according to M. de Caumont, is intimately connected with the inferior oolite.

Mr. Phillips observes (Illustrations, \&c. p. 158), "In the midland counties, the fuller's earth rock of Mr. Smith does by 